\title{
Awareness and Effective use of ICT in Undergraduate Science Classroom Activities
}

\author{
Tasnim Musharrat ${ }^{1 *} \quad$ Sabbir Ahmed Chowdhury ${ }^{2}$ \\ 1.Lecturer, Institute of Education and Research, University of Chittagong, Chittagong, Bangladesh \\ 2.Assistant Professor, Institute of Education and Research, University of Dhaka, Dhaka, Bangladesh
}

\begin{abstract}
Technology-dependency is increasing rapidly. People seek ways to apply technology to simplify complex tasks. Technology is the greatest platform for students to get ready for the world and become successful tech-oriented citizen. Knowledge acquisition needs to follow the current technological trends. Technology-dependency of our country increasing rapidly, students must learn to be tech-orianted. Integrating technology in education helps students to stay engaged. The purpose of the study is to identify the scenario of current trends, awareness and effective use of ICT and digital contents in science classroom of undergraduate students in Bangladesh. This study is focused on two central phenomena naming, 'skills, capabilities and practices' of teachers for appropriate and affordable digital content and ICT based learning' and 'use of digital contents to support collaboration, innovation and effectiveness'. The findings of the study represent that the concept of ICT based learning is not clear for both teachers and students so that classroom practice is not effective. Professional learning opportunities about ICT should be developed to meet the needs of teachers at various stages of knowledge, skills, understanding and practice.
\end{abstract}

Keywords: ICT based learning, digital content, collaboration.

DOI: $10.7176 / \mathrm{JEP} / 11-20-03$

Publication date:July $31^{\text {st }} 2020$

\section{Introduction}

In this techno-based world, teaching becomes the most challenging profession of the market because of continuous up-gradation of knowledge and quick access of information. Students can get the access to updated information by the help of availability of technology. The traditional passive learning mold is breaking. By using technology, teacher becomes the encourager, adviser, and coach. Students can take the responsibility of their own learning. Student can have access to digital textbooks those are constantly updated and often more vivid, creative, and a lot cheaper than those old heavy books. It is prescribed that teacher's should use varieties of method to conduct a class. Still traditional practice is dominant inside the science classrooms and students remain silent observers. But human thirst for knowledge is absolute. Diverse way of teaching is a comfortable way that encourage students towards learning. ICT in education may decrease the challenges related to time and space and provide global access to knowledge (Kazimzade, 2016). Teachers and students can communicate with each other anywhere, anytime. Interactive learning environment involves students and teachers with new way of thinking, motivation and approaches. It can improves skills like digital learning, communication, collaboration, building teams, planning, valuing diversity, problem solving, self-direction, global awareness, presentations. Students can work and collaborate with people in other locations. In today's world, STEM jobs must require ICT skills and there are huge unfilled computing jobs in this area because of lack of skilled people. The purpose of the study is to develop young individuals from today in order to make them successful science professional in future (Kazimzade, 2016). Teacher empowerment is also possible through the proper use of ICT.

Information and Communication Technologies (ICT) provide equal access to learners regardless of gender, geographic location, socio-economic or ethnic background, illness or disability, or any other circumstance that would normally hinder the provision of high-quality higher education. (Broadband Commission Report, p: 9). Twenty-first-century schools require 21st-century programs and educators capable of using 21 st-century resources and strategies for learning (AICTEC 2009, p: 3). In order to consider the implementation of ICT in different subjects it is important to investigate. Teachers have got possibilities of sharing all the relevant and subject-related materials, demonstrating experiments and concepts, assisting students to research on the topic, making better assessment methods (Kazimzade, 2016).

PCAST (2012) report stated that over the next decade, 1 million additional STEM graduates will be needed. The report was based on several analyses such as STEM enrolment, economic analysis STEM workforce need, evidence of the mathematics preparation gap etc. Because of the lack of skilled people many jobs of ICT field will not fulfilled. In that purpose we have to develop young individuals from today in order to make them successful in the future (Kazimzade, 2016). In today's world, ICT based learning using digital content can ensure the proper education for learners. Use of virtual library, sharing the recorded visuals of laboratory work and digital resources can make it available. It has suggested the universities to prepare e-content/e-lab experiment.(UGC-Delhi) 


\section{Purpose and Research Questions of the study}

The purpose of this study is to explain students' views regarding the awareness and effectiveness of using ICT in undergraduate science classroom. Hence, this research is directed towards to explain the current trends and use of ICT and digital content in science classrooms from a learner's point of view. To achieve this purpose, this study will try to find out the following questions -

- What are the teachers' skills and practices about ICT based learning?

- How can digital content support collaborative, innovative and effective teaching-learning?

\section{Methodology}

The study was a quantitative approach work. The population of this study was undergraduate level of students of science group of Institute of Education and Research (IER), University of Chittagong and students of Major Science departments of University of Chittagong. 150 respondents were selected purposefully from science group students of IER, University of Chittagong and students of Major Science departments of University of Chittagong. Data was gathered through field survey through a structured questionnaire supplied to the students. Questionnaire was used to collect data from the students of six departments of University of Chittagong. The quantitative data from the questionnaire were analyzed using simple descriptive statistics.

\section{Findings}

Teachers' skills, capabilities and practice about the use of digital contents and how ICT based learning can facilitate effective teaching-learning were reported in the following sections.

According to Table 1, 46\% students agreed about that they use ICT based digital learning materials in 'Some' science classes. 17\% ticked for 'every' class and 37\% marked that they 'Never' use. Besides, only 4\% students ticked that teacher's use PowerPoint presentation in 'more than enough classes'. 45\% ticked for 'enough to work appropriately' and 51\% for 'less time'. Again, 24\% students marked that teachers provide them with proper information for using computers 'Always' and 48\% marked 'Sometimes', 18\% ticked that teachers 'Never' provide them with proper information.

Table 1. Teachers' usage of ICT based digital learning materials in science classes

How often your teachers use ICT based digital learning materials in science classes?

\begin{tabular}{|c|c|}
\hline Every Class & $17 \%$ \\
\hline Some Class & $46 \%$ \\
\hline Never & $37 \%$ \\
\hline \multicolumn{2}{|c|}{ How much time do you think your teachers use PowerPoint presentation in classrooms? } \\
\hline More than enough & $4 \%$ \\
\hline Enough to work appropriately & $45 \%$ \\
\hline Less time & $51 \%$ \\
\hline \multicolumn{2}{|c|}{ Do you think your teachers provide you with proper information for using computers? } \\
\hline Always & $24 \%$ \\
\hline Sometimes & $48 \%$ \\
\hline Never & $18 \%$ \\
\hline \multicolumn{2}{|c|}{ Amount of digital devices (laptops/computers/projectors) in your science classes are : } \\
\hline Sufficient & $12 \%$ \\
\hline Few Amount & $37 \%$ \\
\hline Little Amount & $61 \%$ \\
\hline \multicolumn{2}{|c|}{ Do you think your teacher as an expert in handling ICT based classroom? } \\
\hline Yes & $30 \%$ \\
\hline No & $45 \%$ \\
\hline Neutral & $35 \%$ \\
\hline \multicolumn{2}{|c|}{ Do your teachers use appropriate digital contents for science classes? } \\
\hline Always & $24 \%$ \\
\hline Sometimes & $53 \%$ \\
\hline Never & $34 \%$ \\
\hline
\end{tabular}


Do you get chances to use computers in your computer labs?

\begin{tabular}{|l|l|}
\hline Always & $12 \%$ \\
\hline Sometimes & $46 \%$ \\
\hline Never & $52 \%$ \\
\hline
\end{tabular}

How do you feel ICT will help you to reflect in your daily modern day life experiences?

\begin{tabular}{|l|l|}
\hline Positive & $72 \%$ \\
\hline Negative & $0 \%$ \\
\hline Neutral & $28 \%$ \\
\hline
\end{tabular}

Do you think ICT helps you in your science concept building?

\begin{tabular}{|l|l|}
\hline Always & $83 \%$ \\
\hline Sometimes & $24 \%$ \\
\hline Never & $3 \%$ \\
\hline
\end{tabular}

In addition, Only $12 \%$ students agreed that amount of digital content (laptops/computers/projectors) in science classes are 'Sufficient', 37\% marked 'few amount' and 61\% marked a 'little amount'. According to Table 1, $45 \%$ students' think their teachers are not expert in handling ICT based classroom, 30\% think they are and 35\% remain 'Neutral'. Besides, 53\% students marked that teachers use appropriate digital contents for science classes 'Sometimes', 24\% marked 'Always' and 34\% marked 'Never'. In addition, 12\% students 'Always' get chances to use computers in computer labs, $46 \%$ 'Sometimes' and 52\% 'Never'. Again, $72 \%$ feel ICT will 'Positively' help to reflect in their daily modern day life experiences and $28 \%$ feel 'Neutral' and there is no negative feeling about it. In addition, $83 \%$ think ICT 'Always' helps them to science concept building and 24\% 'Sometimes'. Only $3 \%$ marked negatively (Table 1 ).

Table 2. Comparing 'learning science using digital content' with 'traditional method'

\begin{tabular}{|l|l|}
\hline Category & $\%$ \\
\hline Learning science using 'digital content' is better than 'traditional method' & $92 \%$ \\
\hline 'traditional method' is better than learning science using 'digital content' & $3 \%$ \\
\hline There is no difference & $5 \%$ \\
\hline
\end{tabular}

According to Table 2, 92\% students ticked on that 'learning science using digital content' is better than 'traditional method (only textbook based)', 3\% ticked on 'traditional method' as better option and 5\% marked on 'no difference'.

\section{Discussion}

This study is focused on the students' perspective so their opinions about the current classroom practices of ICT are the main outcomes of the research. According to the study, the scenario of ICT laden classroom is not effective. Teachers are trying to use ICT and digital content based classroom but maximum time without applying the proper strategy. They are not aware about the effectiveness of ICT based class in their classes. In maximum cases, the concept about ICT based learning is only the lecture based power point presentation. ICT based classroom means not only by conducting the class through power point presentations but also learning friendly environment will be focused. Students' learning is not ensured in maximum time. Power point presentation is making both teachers and students reluctant and the importance of exploring something or thirst of knowledge is reducing. Most alarming is that both teachers and students consider power point presentation as the only digital contain in conducting a science class. They have lack of proper idea about what can be the scenario and equipment of ICT based class. Introducing and conducting ICT based class are important but the procedures should be accurate and effective. According to the second research questions, finding the importance of digital content to support collaborative, innovative and effective teaching-learning are completely failed in this study. The practice is not in major quantity to measure this. These are not significantly found in teachers' practice according to the students' opinion. But students prefer learning using digital content on traditional learning. Proper training and utilization of ICT for both teachers' and students' can make this possible.

\section{Recommendations}

The most positive thing is that students are very much aware and interested about ICT based learning. According to our findings, following recommendations are suggested:

i Professional learning opportunities about ICT should be developed to meet the needs of teachers at various stages of knowledge, skills, understanding and practice.

ii Professional learning should include an understanding of learning theories relevant to the new forms of learning, collaboration, innovation and communication. 
iii Availability of accessible, high-quality digital contents and technology-rich learning environments are prerequisite to ensure effective use of ICT in classroom activities.

iv Internet access should be free and strong connectivity should be assured. Investment in this sector is not sufficient to support the huge population of the country like Bangladesh. It is difficult to support even faculty members, students perspective is beyond imagination. This problem should be handled sincerely and effectively.

v Students think that ICT based classroom is not only that where teacher is conducting the classes using ICT but also students are using digital materials as well. To support this availability of digital materials should be ensured.

This study is a primary work of the researchers. Further research in this field can explore the overall scenario of the problem and find some effective solutions to improve the current situation.

\section{References}

Australian Information \& Communications Technology in Education Committee 2009, 'The Digital Education Revolution: Teaching for the Digital Age Work Plan 2009-2012', AICTEC, Australia.

Becker, H. J. (2000). 'Pedagogical Motivations for Student Computer Use that Leads to Student Engagement'. Education Technology. Vol. 40, No. 5, (pp. 5-17).

Bhattacharya, I. \& Sharma, K. (2007). 'India in the knowledge economy - an electronic Paradigm', International Journal of Educational Management, Vol. 21 No. 6, (pp. 543-568).

Kazimzade, G. (2016).ICT in Education - Science, Technology, Engineering and Mathematics. Jonassen, D. H., Peck, K. L., \& Wilson, B. G. (1999). 'Learning with technology: A constructivist perspective'. Upper Saddle River, NJ: Merrill.

Meyer, E., Abrami, P., Wade, A., \& Scherzer, R. (2011). 'Electronic portfolios in the class-room: Factors impacting teachers' integration of new technologies and new pedagogies'. Technology, Pedagogy, and Education, 20(2), 191-207.

National Council of Teachers of English. (2008). NCTE Framework for 21st Century Curriculum and Assessment. Retrieved from: http://www.ncte.org/governance/21 stcenturyframework.

OECD (2015). Better Skills, Better Jobs, Better Lives. Available at: http://www.oecd.org/countries/unitedarabemirates/A-Strategic-Approach-to Education

UNESCO, (2002). 'Open and Distance Learning Trends, Policy And Strategy Considerations', 14

UNESCO.

Webb, M., \& Cox, M. (2004). A review of pedagogy related to information and Communications technology. Technology, Pedagogy and Education, Vol. 13 No. (3), pp. (235-286).

Wheeler, S. (2001). 'Information and communication technologies and the changing role of the teacher.' Journal of Educational Media, Vol. 26, No. (1).

Young, J. (2002). The 24-hour professor. The Chronicle of Higher Education, Vol. 48, No. (38), pp. (31-33).

Zhao, Y. \& Cziko, G. A. (2001). Teacher adoption of technology: a perceptual control theory perspective.Journal of Technology and Teacher Education, Vol. 9, No. (1), pp. (5-30). 